\title{
IS THE POSITIVE BIOPSY CORE PERCENT REALY PREDICTIVE OF NON-ORGAN CONFINED PROSTATE CARCINOMA?.
}

Fikret Fath Ö nol, A. Ö zgür and LN. Türkeri.

Department of Urology. Marmara University School of M edicine. M armara University Hospital. Istanbul. Turkey.

\begin{abstract}
Summary.- $O$ BJEC TIVES: In this study, we investigated the association of positive biopsy core percent (PBCP), as well as other preoperative factors, with prostate cancer outcomes in a cohort of consecutive patients with clinically localized prostate cancer who underwent RRP.

METHODS: Data from 203 patients who underwent RRP from March 1993 to May 2004 for clinically organ confined prostate cancer was analysed. The correlation of preoperative serum prostate specific antigen (PSA) level, biopsy $G$ leason score, to tal number of positive biopsies and PBCP with the extent of disease at final pathology and biochemical progression were analyzed.
\end{abstract}

RESULTS: The mean PBCP was 29.8 21.1 (median $25)$. Histo pathological examination of the RRP specimens revealed ECE in 66 (32.5\%), SVI in 43 (21.2\%), LN I

Fikret Fatih Ö N O L, M D.

M a rmara U niversity Hospital

Department of U rology

Tophanelioglu C d. $13 / 15$

Altunizade (34662)

Istanbul, Turkey

e-mail: ffonol@yahoo.com

Trabajo recibido: 1 de marzo 2004 in 8 (4\%), and positive SM in 59 (29.1\%). O verall, only $9 \%$ of patients (18 of 203 ) had biochemical progression at a median postoperative follow-up of 22 months. Univariate analysis revealed serum PSA, biopsy $G$ leason Score, the number of positive cores and $P B C P$ as predictive factors for extra-prostatic disease in RRP specimens. How ever, multivaria te a nalysis revealed that biopsy Gleason score and serum PSA were the strongest independent predictive factors for extra-prostatic disease while percent positive biopsy cores carried significance in the prediction of ECE and SM positivity. The number of positive cores was not a predictor of non-organ confined disease. Preoperative serum PSA was the only prognostic factor for determination of biochemical failure.

CONCLUSION: G leason score is the most important and independent predictive factor for extra-prostatic disease. The percentage of cores positive for cancer has significance only in the prediction of ECE and SM positivity. Further studies are needed before routine use of PBC $P$ as one of the important preoperative prognostic factors.

Keywords: Prostatic neoplasm. Prognostic factors. Positive biopsy core percent

Resumen.- OBJETIVOS: Investigamos la asociación entre el porcentaje de afectación de los cilindros de biopsia y los parámetros clínicos preoperatorios, y la evolución del cáncer de próstata en una cohorte de pacientes con cáncer de prósta ta localizado intervenidos mediante prostatectomía radical retropúbica (PRR) de forma consecutiva. 
M ÉTO DO S: Análisis retrospectivo de los datos de 203 pacientes con cáncer de próstata clínicamente órganoconfinado intervenidos de PRR entre Marzo de 1993 y $M$ ayo del 2004. Se analiza la correlación del PSA preoperatorio, el G leason en la biopsia, el número total de biopsias positivas y el porcentaje de afectación en la biopsia con la extensión de la enfermedad en el estudio a natomopatológico final y la progresión bioquímica.

RESULTADO S: El porcentaje medio de afectación de los cilindros fue de 29,8 $\pm 21,1$ (mediana 25). El análisis a natomopatológico de los especimenes quirúrgicos reveló extensión extracapsular en 66 casos (32,5\%), invasión de las vesículas seminales en $43(21,2 \%)$, a fectación ganglionar en 8 (4\%) y márgenes quirúrgicos positivos en 59 $(29,1 \%)$. G lobalmente, sólo el $9 \%$ de los pacientes (18 de 203) presentaron progresión bioquímica con un tiempo medio de seguimiento de 22 meses. El análisis univariante reveló que el $\mathrm{G}$ leason en la biopsia, el número de cilindros afectos y el porcentaje de afectación eran factores predictivos de enfermedad extraprostática en el espécimen de la PRR. Sin embargo, en el a nálisis multivariante el $G$ leason y el PSA sérico eran los factores predictivos independientes más potentes de enfermedad extraprostática, mientras que el porcentaje de afectación de las biopsias tenia significación en la predicción de extensión extracapsular y márgenes positivos. El número de cilindros no fue predictivo de enfermedad extraprostática. EI PSA preoperatorio fue el único factor pronóstico para la determinación de progresión bioquímica.

CO N C LUSIO N ES: La puntuación de G leason es el factor independiente más importante en la predicción de enfermedad extraprostática. El porcentaje de los cilindros positivo para cáncer sólo tiene significación en la predicción de extensión extracapsular y márgenes quirúrgicos positivos. Son necesarios más estudios antes de utilizar rutina ria mente el porcentaje de afectación de los cilindros como uno de los factores pronósticos preopera torios importantes.

Palabras clave: $N$ eoplasia prostática. Factores pronósticos. Porcentaje de positividad en los cilindros de biopsia.

\section{OBJ ECTIVES}

The number of patients diagnosed with localized prostate cancer is rising due to the widespread use of serum prostate specific antigen (PSA) screening (1). Radical retropubic prostatectomy (RRP) is a common therapeutic procedure performed when clinically organ confined prostate cancer is diagnosed $(2,3)$.
Unfortunately, histopathological examination will reveal positive surgical margin(s) (SM) approximately in one third $(24-42 \%)(4,5)$ and seminal vesicle invasion (SVI) in $1-33.3 \%(6,7)$ of the patients who undergo surgery with curative intent. These patients will have an increased risk of local and/ or systemic cancer progression.

The pre-operative identification of patients at risk for non-organ confined cancer may be helpful for selection of the candidates for wide excision of the neurovascular bundles as well as extended lymphadenectomy (8). Currently, serum PSA, biopsy Gleason score and clinical T stage are the most commonly used parameters in predicting the risk of non-organ confined disease, lymph node involvement (LNI) and PSA progression after treatment (9). In recent studies, factors such as quantitative nuclear grade (16), total percent cancer in biopsy cores (11), a combination of percent positive biopsy (greater than $50 \%)$, and the number of positive cores (12-15) have been found to improve the prediction of pathologic stage. The percentage of cancer in prostate biopsy cores was found to be associated with the risk of extracapsular extension (16). Also, the number of positive biopsies were proposed to improve the prediction of margin status (17), while PBCP has been shown to help predict the risk of PSA relapse (18) and time to PSA failure after RRP (7).

To confirm these findings and further assess the hypothesis that a proportion of men with biologically aggressive clinically localized prostate cancer would have higher PBCP, we investigated the association of percentage of positive biopsies with other preoperative factors, as well as prostate cancer outcomes in a cohort of consecutive patients with clinically localized prostate cancer who underwent RRP.

\section{MATERIALS AND METHODS}

A retrospective analysis were performed on 203 patients who underwent RRP with bilateral pelvic lymphadenectomy in our department between March 1993 and May 2004 with the diagnosis of clinically organ confined prostate cancer. Pre-operative data, including patient age, digital rectal examination (DRE), serum PSA level, transrectal ultrasound (TRUS) results, primary and secondary Gleason grades from the 
biopsy, G leason score, the number of positive biopsies, and the percent of cores positive for cancer were recorded.

A Il prostate needle biopsy samples were taken via ultrasound guidance with an 18 gauge Tru-Cut needle. The median number of prostate needle biopsy cores taken was 10 (mean 9.82, range 4 to 24). Patients with less than 4 prostate needle biopsy cores were excluded from this study. Percent of cores with cancer was determined by dividing the number of cores with cancer by the total number of cores obtained and multiplying by 100 . Staff pathologists at our institution examined all prostatectomy specimens pathologically, as previously described (19). Multiple, oriented quadrant sections from the entire prostate were processed. The 1997 TN M staging system was used to classify the stage, and tumor grading was performed according to the Gleason system. Specimens before 1997 were re-staged according to the new classification.

Patients were scheduled to have DRE and serum PSA evaluation postoperatively every 3 months for year 1 , semiannually from years 2 through 5 and annually thereafter. Biochemical progression was defined as a sustained increase of serum total PSA on 2 or more occasions of $0.2 \mathrm{ng} / \mathrm{ml}$. or greater and it was assigned to the date of the first value of $0.2 \mathrm{ng} / \mathrm{ml}$. or greater.

Preoperative PSA, biopsy G leason score, extent of biopsy involvement, including number of positive cores involved and percentage of positive biopsies were evaluated for association with extracapsular extension (ECE), seminal vesicle invasion (SVI), regional lymph node involvement (LNI), surgical margin status (SM), and biochemical progression (BP) with univariate analysis. Multivariate analysis was performed using stepwise logistic regression, including only significant variables in the univariate analysis. All reported $p$ values are 2 -tailed, with $p<0.05$ considered statistically significant. All analysis were performed using the statistical package SPSS, version 10.0 for $W$ indows (SPSS, Inc., Chicago, Illinois).

\section{RESULTS}

Mean patient age in this study was $63.7 \pm 6.5$ years (median 65, range 47 to 77 ). Mean pre-operative serum PSA level of all patients was $9.8 \pm 6.9 \mathrm{ng} / \mathrm{ml}$. (median 8.1 , range 0.1 to 40.4 ). Mean number of biopsies was $9.8 \pm 3.2$ (median 10 , range 4 to 24 ), mean number of positive biopsies was $2.8 \pm 2.1$ (median 2, range 1 to 12 ) and mean PBCP was 29.8 \pm 21.1 (median 25 , range 5.6 to 100 percent). $0 \mathrm{n}$ histopathological examination of the RRP specimens 66 $(32.5 \%)$ patients were found to have estracapsular extensión (ECE), 43 (21.2\%) had seminal vesicle involvement (SVI), 8 (4\%) had lymph node involvement (LNI), and 59 (29.1\%) had positive surgical margin (SM). O verall only $9 \%$ of patients (18 of 203 ) had biochemical progression at a median post-operative follow-up of 22 months.

Median PSA level was 9.2 (mean $12.5 \pm 8.9$ ) $\mathrm{ng} / \mathrm{ml}$ in patients with ECE, 10.3 (mean $13.4 \pm 9.1$ ) $\mathrm{ng} / \mathrm{ml}$ in patients with SVI, 14.3 (mean $18.4 \pm 10.5$ ) $\mathrm{ng} / \mathrm{ml}$ in patients with $\mathrm{LNI}, 10.1$ (mean 12.8 \pm 8.6 ) $\mathrm{ng} / \mathrm{ml}$ in patients with positive SM and 11.3 (mean $13.7 \pm 9.4)$ in patients with BP while median serum PSA level was 7.3 (mean $8.5 \pm 5.2$ ) ng/ ml, 7.3 (mean $8.8 \pm 5.8) \mathrm{ng} / \mathrm{ml}, 7.7$ (mean $9.4 \pm 6.5$ ) ng/ ml, 7 (mean $8.5 \pm 5.6) \mathrm{ng} / \mathrm{ml}$ and 7.3 (mean $9.3 \pm 6.7$ ) $\mathrm{ng} / \mathrm{ml}$ in patients without ECE $(p=0.001), S V I(p=0.003), L N$ I $(p<0.001)$, positive SM $(p=0.001)$ or BP $(p=0.015)$, respectively.

Median G leason score in TRUS biopsy specimens was observed to be higher in patients with $L N I$ at final pathology (Score of 8 , mean $7.8 \pm 1.0$ ) followed by SVI (Score of 7, mean $6.7 \pm 1.3$ ) and ECE (Score of 7, mean $6.4 \pm 1.4)$. Patients with $S M$ and $B P$ had a median Gleason score of 6 (mean $6.4 \pm 1.4$ and 6.5 \pm 1.5 , respectively). Respective median $\mathrm{G}$ leason score was 6 in patients without LNI (mean $5.8 \pm 1.4$, $p=0.001)$, SVI (mean $5.6 \pm 1.4, p<0.001)$, ECE (mean $5.6 \pm 1.4, p<0.001)$, positive SM (mean $5.6 \pm 1.4$, $p<0.001)$ or BP (mean $5.7 \pm 1.4, p=0.036)$.

Median number of positive biopsy cores was 4.5 (mean $4.3 \pm 2.5$ ) in patients with LN I, 3 in patients with $\mathrm{ECE}, \mathrm{SM}$ and $\mathrm{BP}$ (mean $3.5 \pm 2.5,3.4 \pm 2.3,2.8$ \pm 1.5 , respectively), and 2 (mean $3.0 \pm 2.2$ ) in patients with SVI while it was 2 in patients without any LN I (mean $2.7 \pm 2.0, p=0.046)$, ECE (mean $2.5 \pm 1.7$, $\mathrm{p}=0.001$ ), positive $\mathrm{SM}$ (mean $2.6 \pm 1.9, \mathrm{p}=0.01)$, BP (mean $2.9 \pm 2.3, p>0.05$ ) or SVI (mean $2.7 \pm 2.0, p>$ 0.05).

Median percentage of cores positive for cancer was 33.3 (mean $38.7 \pm 24.6$ ) and 22.2 (mean $25.6 \pm$ 17.9 ) in patients with and without ECE, respectively 
$(p<0.001)$. Similarly, patients with SVI had a median $33.3 \%$ (mean $36.8 \pm 24.1$ ) positive biopsy cores and this was significantly higher than the patients without any SVI (median 25, mean $37.9 \pm 19.9, p=0.016$ ). The above findings were also observed with respect to SM (median 33.3, mean $36.7 \pm 23.3$ vs. median 23, mean $26.9 \pm 19.6, p=0.003$ ). Patients with $L N I$ had the highest percentage of positive biopsy cores (median 43.7, mean $43.9 \pm 21.9$ ). However, the difference was not statistically significant when compared with patients without any LNI (median 25, mean $29.2 \pm 20.9, p=0.054)$ although there was a clear trend indicating higher PBCP associated with LN I. Likewise, there was no statistically significant difference between patients with and without BP (median 33.3, mean $38.2 \pm 21.1$ vs. median 25 , mean $30.5 \pm 22.7, p>0.05$ ) in terms of PBCP.
The correlation of preoperative findings with postoperative pathology results regarding ECE, SVI, LN I, SM positivity and BP are summarized in Table I. Sensitivity and specificity of preoperative serum PSA, biopsy Gleason score and percent positive biopsy cores in the prediction of ECE, SVI, LNI, SM positivity and $B P$ were assessed by ROC curves where "Area Under the Curve $(A \cup C)$ " values for each factor was calculated and compared with others (Table II). Percent positive biopsy core had higher sensitivity and specificity than preoperative serum PSA in predicting ECE, however it was weaker than other preoperative factors in terms of predicting LN I, SM positivity and BP accurately.

Multivariate logistic-regression a nalysis revealed that $\mathrm{PBCP}$, Gleason score and serum PSA were significant independent factors in the prediction

TABLE I. The correlation of preoperative findings with postoperative pathology results regarding ECE, SVI, LN I, SM and $B P$.

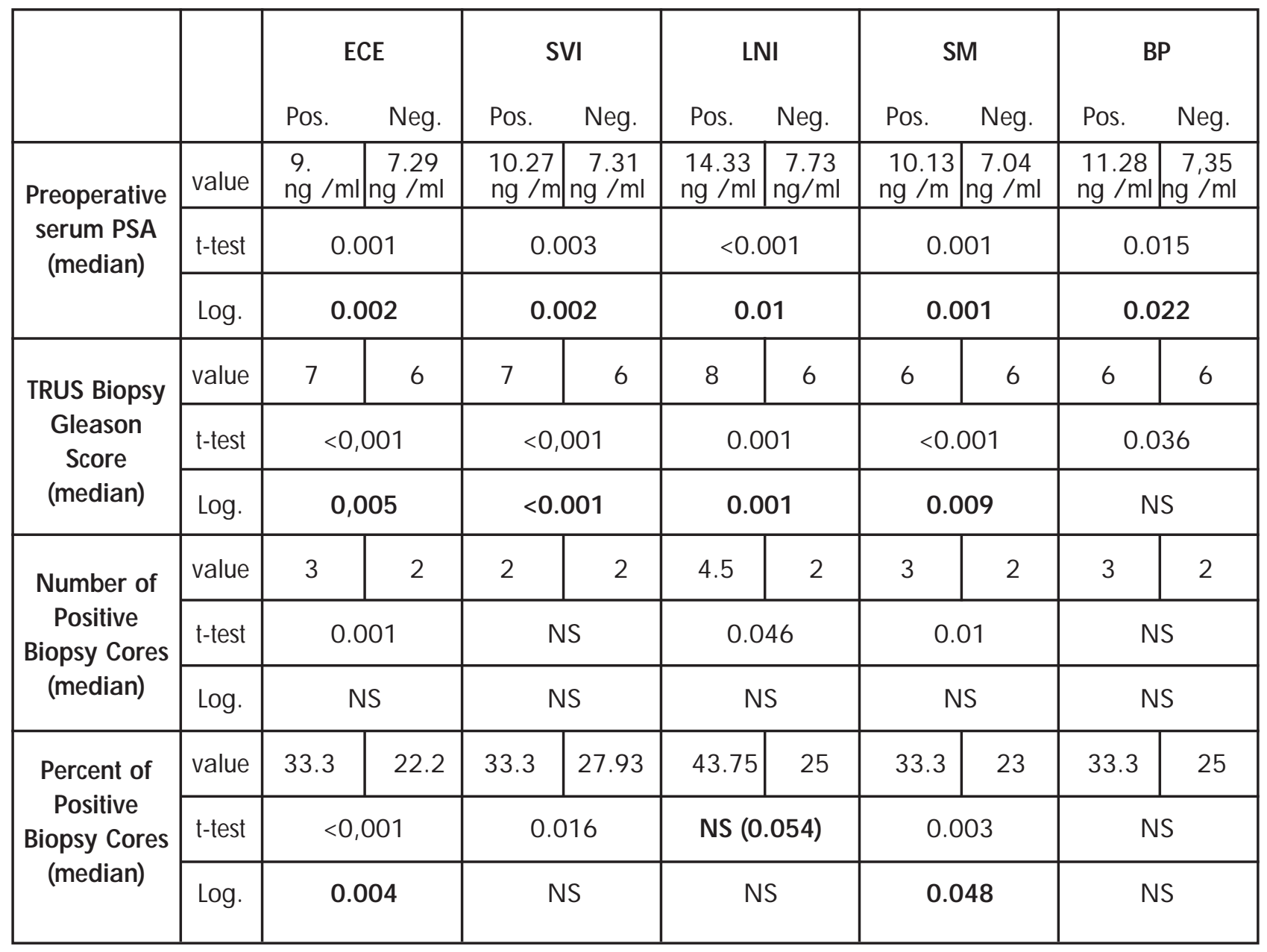


of ECE and positive SM. G leason score and serum PSA were also significant independent factors in the prediction of SVI and LN I, while only serum PSA had significance in predicting $\mathrm{BP}$.

\section{DISCUSSION}

Knowledge of the true extent of prostate cancer is an important factor for determining appropriate treatment. The ability to determine accurately if a cancer is organ confined may help differentiate patients who can undergo nerve sparing radical prostatectomy and patients who are best candidates for brachytherapy or external beam radiation therapy. Furthermore, predicting which patients are at high risk for PSA failure may assist in selecting those who may benefit from neoadjuvant and/ or adjuvant therapy.

Prediction of pathological stage of clinically localized prostate cancer using the combination of preoperative PSA, clinical stage and biopsy G leason score has been studied extensively, and nomograms and equations have been published based on large databases. A multicenter study based on 4133 cases was published in 1997 by Partin and his colleagues (9) in an effort to predict the probability of histopathologically organ confined disease. Current nomograms using preoperative serum PSA, clinical stage and Gleason score are insufficient to predict the patients in whom local therapy may fail (9). Even with pathologically confined disease $10 \%$ to $26 \%$ of patients experience clinical recurrences $(20)$.

Multiple studies have evaluated the association between initial biopsy characteristics and postoperative pathological features. The extent of tumor involvement in prostate needle biopsy cores alone or in conjunction with other preoperative parameters, such as PSA, biopsy G leason score and clinical stage, has commonly been used to determine prognostic criteria that can reduce the under staging of clinically localized prostate cancer. However, results from various series have been mixed and inconsistent $(12,14,21-28)$. G rossklaus et al found a correlation between percent tumor in the biopsy set and the risk of ECE $(p<0.01)$ (16). Bismar et al found that total percent cancer in biopsy cores was significantly related to pathological $T$ stage on multivariate analysis ( $p=0.003$ ) (11). Additional supporting evidence that percentage of tumor involvement in the biopsy specimen was an independent predictor of rate of organ confined disease has been confirmed in 3 other reports $(12,24,29)$. The number of positive biopsy cores as an independent predictor of the risk of non-organ confined disease also has been reported $(14,25)$. However, there is also evidence indicating that biopsy features are not independent predictors of final pathological findings $(22,23,26,27,30)$.

TABIE II: RO C analysis results ("Area Under the C urve" values) in determination of the efficacy of various clinilcal parameters

\begin{tabular}{|c|c|c|c|c|c|}
\hline & ECE & SVI & LNI & SM & BP \\
\hline $\begin{array}{c}\text { Preoperative } \\
\text { serum PSA }\end{array}$ & 0.623 & 0.670 & 0.804 & $\mathbf{0 . 6 7 8}$ & $\mathbf{0 . 6 8 6}$ \\
$(p=0.002)$ & $(p<0.001)$ & $(p=0.003)$ & $(p<0.001)$ & $(p=0.003)$ \\
\hline $\begin{array}{c}\text { Biopsy } \\
\text { Gleason Score }\end{array}$ & $\mathbf{0 . 6 7 6}$ & $\mathbf{0 . 6 9 6}$ & $\mathbf{0 . 8 7 3}$ & 0.656 & 0.633 \\
\hline $\begin{array}{c}\text { Percent of } \\
\text { Positive } \\
\text { Biopsy Cores }\end{array}$ & 0.667 & 0.612 & 0.727 & 0.633 & $(p=0.038)$ \\
\hline
\end{tabular}


D'A mico et al evaluated the predictive value of percent positive prostate biopsy in 960 patients and found a statistically significant correlation between increased percent positive biopsies, and increased extracapsular extension and seminal vesicle invasion $(p<0.0001)$ (7). Freedland et al provided evidence that percent of cores positive for cancer was a strong independent predictor of seminal vesicle invasion and nonorgan confined disease, and was a stronger predictor of biochemical recurrence than either PSA $(p=0.048)$ or biopsy G leason score $(p=0.053)$ (31). In a recent study, Lotan et al confirmed that percent positive prostate biopsy was associated with established pathological features, biochemical progression, distant metastasis and overall death in patients who undergo RRP, and claimed that it should be included in preoperative predictive models for prognostic outcome measures after primary treatment (32). However, similar to some of the previously reported studies in the literature, our data concerning percentage of cores positive for cancer found to be significant only in the prediction of ECE and SM positivity ( $p=0.004$ and $p=0.048$, respectively) while both serum PSA and biopsy G leason score were strong independent predictors of ECE, SVI, LN I and SM positivity. Serum PSA was found to be the sole significant factor in the prediction of BP $(p=0.02)$.

The number of positive cores has been found to correlate with stage in multiple studies (12-15). In a similar study the number of positive sextant biopsies was found to predict the margin status at radical prostatectomy (17). Because biopsy schedules vary widely in number of biopsy cores, it may be more difficult to use the number of positive cores in a uniform matter. Meanwhile, in our study group the number of positive biopsies had no significance in prediction of any of the non-organ confined disease parameters on postoperative pathology.

Multivariate analysis of our data set revealed that biopsy Gleason score and preoperative serum PSA were the most important independent variables in predicting extra-prostatic disease, biopsy Gleason score being more sensitive and specific. Value of percent positive biopsy cores was limited to prediction of ECE and SM positivity. Meanwhile, several limitations in this study should be considered. Follow-up was limited to a median of close to 2 years. Some variables that were inconclusive due to limited statistical power may atta in statistical significance if sample size, follow-up or the proportion of patients with biochemical failure or clinical progression were greater. $N$ evertheless, we believe our results indicate a relatively limited importance of PBCP and requires further verification before it can be equivocally included in predictive nomograms.

\section{CONCLUSION}

O ur data indicated that biopsy G leason score was the strongest independent factor in the prediction of extra-prostatic disease. Preoperative serum PSA was the only predictor of biochemical progression. Percentage of cores positive for cancer had significance only in the prediction of ECE and SM positivity while the number of positive cores did not correlate with non-organ confined disease. Thus, a conclusion is reached that it is still too early to regard percentage of positive biopsy cores and the number of positive cores as important preoperative prognostic factors, and further studies are required.

\section{BIBUOGRAFIA y LECTURAS RECOMENDADAS (*lectura de interés y $* *$ lectura fundamental)}

1. MetTlin, C.: "The American Cancer Society National Prostate Cancer Detection Project and national patterns of prostate cancer detection and treatment”. CA Cancer J. Clin., 47: 265, 1997.

2. GERBER, G.S.; THISTED, R.A.; SCARDINO, P.T. y cols.: "Results of radical prostatectomy in men with clinically localized prostate cancer". JAMA, 276: 615, 1996.

3. ZINCKE, H.; OESTERLING, J.E.; BLUTE, M.L. y cols.: "Long-term (15 years) results after radical prostatectomy for clinically localized (stage T2c or lower) prostate cancer". J. Urol., 152: 1850, 1994.

4. BLUTE, M.L.; BERGSTRALH, E.J.; IOCCA, A. y cols.: "Use of Gleason score, prostate specific antigen, seminal vesicle and margin status to predict biochemical failure after radical prostatectomy". J. Urol., 165: 119, 2001.

5. CHENG, L.; SLEZAK, J.; BERGSTRALH, E.J. y cols.: "Preoperative prediction of surgical margin status in patients with prostate cancer treated by radical prostatectomy”. J. Clin. Oncol., 18: 2862, 2000.

*6. D'AMICO, A.V.; WHITTINGTON, R.; MALKOWICZ, S.B. y cols.: "The combination of preoperative prostate specific antigen and postoperative pathological findings to predict prostate specific antigen outcome in clinically localized prostate cancer". J. Urol., 
160: 2096, 1998.

*7. D’AMICO, A.V.; WHITTINGTON, R.; MALKOWICZ, S.B. y cols.: "Clinical utility of the percentage of positive prostate biopsies in defining biochemical outcome after radical prostatectomy for patients with clinically localized prostate cancer". J. Clin. Oncol., 18:1164, 2000.

8. SMITH, R.C.; PARTIN, A.W.; EPSTEIN, J.I. y cols.: "Extended follow-up of the influence of wide excision of the neurovascular bundle(s) on prognosis in men with clinically localized prostate cancer and extensive capsular perforation". J. Urol., 156: 454, 1996.

**9. PARTIN, A.W.; KATTAN, M.W.; SUBONG, E.N. y cols.: "Combination of prostate-specific antigen, clinical stage, and Gleason score to predict pathological stage of localized prostate cancer: A multi-institutional update". JAMA, 277: 1445, 1997.

10. VELTRI, R.W.; MILLER, M.C.; MANGOLD, L.A. y cols.: "Prediction of pathological stage in patients with clinical stage T1c prostate cancer: the new challenge". J. Urol., 168: 100, 2002.

11. BISMAR, T.A.; LEWIS, J.S. Jr.; VOLLMER, R.T. y cols.: "Multiple measures of carcinoma extent versus perineural invasion in prostate needle biopsy tissue in prediction of pathological stage in a screening population”. Am. J. Surg. Pathol., 27: 432, 2003.

*12. WILlS, M.L.; SAUVAGEOT, J.; PARTIN, A.W. y cols.: "Ability of sextant biopsies to predict radical prostatectomy stage". Urology, 51: 759, 1998.

13. BORIRAKCHANYAVAT, S.; BHARGAVA, Y.; SHINOHARA, K. y cols.: "Systematic sextant biopsies in the prediction of extracapsular extension at radical prostatectomy". Urology, 50: 373, 1997.

14. PELLER, P.A.; YOUNG, D.C.; MARMADUKE, D.P. y cols.: "Sextant prostate biopsies. A histopathological correlation with radical prostatectomy specimens". Cancer, 75: 530, 1995.

15. HULAND, H.; HAMMERER, P.; HENKE, R.P. y cols.: "Preoperative prediction of tumor heterogeneity and recurrence after radical prostatectomy for localized prostatic carcinoma with digital rectal examination, prostate specific antigen and the results of 6 systematic biopsies". J. Urol., 155: 1344, 1996.

**16. GROSSKLAUS, D.J.; COFFEY, C.S.; SHAPPELL, S.B. y cols.: "Percent of cancer in the biopsy set predicts pathological findings after prostatectomy". J. Urol., 167: 2032, 2002.

17. TIGRANI, V.S.; BHARGAVA, V.; SHINOHARA, K. y cols.: "Number of positive systematic sextant biopsies predicts surgical margin status at radical prostatectomy". Urology, 54: 689, 1999.

18. PRESTI, J.C. Jr.; SHINOHARA, K.; BACCHETTI, P. y cols.: "Positive fraction of systematic biopsies predicts risk of relapse after radical prostatectomy". Urology, 52: 1079, 1998.

19. HALL, G.S.; KRAMER, C.E.; EPSTEIN, J.I.: "Evaluation of radical prostatectomy specimens. A comparative analysis of sampling methods". Am. J. Surg. Pathol., 16: 315, 1992.
20. LERNER, S.E.; BLUTE, M.L.; BERGSTRALH, E.J. y cols.: "Analysis of risk factors for progression in patients with pathologically confined prostate cancers after radical retropubic prostatectomy". J. Urol., 156: 137, 1996.

*21. RAVERY, V.; SCHIMD, H.P.; TOUBLANC, M. y cols.: "Is the percentage of cancer in biopsy cores predictive of extracapsular disease in T1-T2 prostate carcinoma?" Cancer, 78: 1079, 1996.

22. BRINKER, D.A.; ROSS, J.S.; TRAN, T.A. y cols.: "Can ploidy of prostate carcinoma diagnosed on needle biopsy predict radical prostatectomy stage and grade?" J. Urol., 162: 2036, 1999.

23. SANWICK, J.M.; DALKIN, B.L.; NAGLE, R.B.: "Accuracy of prostate needle biopsy in predicting extracapsular tumor extension at radical prostatectomy: application in selecting patients for nerve-sparing surgery". Urology, 52: 814, 1998.

24. BOSTWICK, D.G.; QIAN, J.; BERGSTRALH, E. Y cols.: "Prediction of capsular perforation and seminal vesicle invasion in prostate cancer". J. Urol., 155: 1361, 1996.

25. BADALAMENT, R.A.; MILLER, M.C.; PELLER, P.A. y cols.: "An algorithm for predicting non-organ confined prostate cancer using the results obtained from sextant core biopsies with prostate specific antigen level". J. Urol., 156: 1375, 1996.

26. HUMPHREY, P.A.; BATY, J.; KEETCH, D.: "Relationship between serum prostate specific antigen, needle biopsy findings, and histopathological features of prostatic carcinoma in radical prostatectomy tissues". Cancer suppl., 75: 1842, 1995.

27. GOTO, Y.; OHORI, M.; SCARDINO, P.T.: "Use of systematic biopsy results to predict pathological stage in patients with clinically localized prostate cancer: a preliminary report". Int. J. Urol. 5: 337, 1998.

28. OGAWA, O.; EGAWA, S.; ARAI, Y. y cols.: "Preoperative predictors for organ-confined disease in Japanese patients with stage T1c prostate cancer". Int. J. Urol., 5: 454, 1998.

*29. D'AMICO, A.V.; WHITTINGTON, R.; MALKOWICZ, S.B. y cols.: "Combined modality staging of prostate carcinoma and its utility in predicting pathologic stage and postoperative prostate specific antigen failure". Urology, 49: 23, 1997.

30. RABBANI, F.; GOLDENBERG, S.L.; KLOTZ, L.H. y cols.: "Predictors of pathological stage before neoadjuvant androgen withdrawal therapy and radical prostatectomy”. J. Urol., 159: 925, 1998.

**31. FREEDLAND, S.J.; CSATHY, G.S.; DOREY, F. y cols.: "Percent prostate needle biopsy tissue with cancer is more predictive of biochemical failure or adverse pathology after radical prostatectomy than prostate specific antigen or Gleason score”. J. Urol., 167: 516, 2002.

32. LOTAN, Y.; SHAHROKH, F.S.; SEYED, M.K. y cols.: "The percent of biopsy cores positive for cancer is a predictor of advanced pathological stage and poor clinical outcomes in patients treated with radical prostatectomy". J. Urol., 171: 2209, 2004. 